\title{
Charlie ant insect bite-associated preseptal cellulitis
}

Patricia Ann John ${ }^{1}$, Sylves Patrick ${ }^{1,2}$, Ngoo Qi Zhe ${ }^{1}$, Wan Hazabbah Wan Hitam ${ }^{1}$, Adil Hussein ${ }^{1}$

${ }^{1}$ Department of Ophthalmology, School of Medical Sciences, Universiti Sains Malaysia Health Campus, Kota Bharu, Kelantan, Malaysia; ${ }^{2}$ Faculty of Medicine and Health Sciences Universiti Malaysia Sabah, Kota Kinabalu, Sabah, Malaysia

\section{Abstract}

Preseptal cellulitis is a worrying condition in children. One of the commonest causes is from insect bite. The Charlie ant or Paederus fuscipes has been reported as a dermatitis-causing agent due to its toxin, pederin. The aim is to report a case of preseptal cellulitis secondary to Charlie ant insect bite. A two-year-old girl presented with bilateral eyelid swelling, redness, and pain for two days. The Charlie ant was at the nasal bridge before the presentation. There was presence of generalised bilateral eyelid swelling, redness with multiple pustules, excoriated skin, and eye discharge. She was admitted and started on antibiotics. The pustules ruptured, left the skin exposed, and her condition improved. Preseptal cellulitis is a contiguous spread of infection. An attack by Charlie ant has become a public health concern. There is no specific treatment for this condition. Early detection may prevent complications.

Keywords: Charlie ant, eyelid swelling, insect bite, Paederus fuscipes, preseptal cellulitis

Correspondence: Dr. Adil Hussein, AM (Malaysia), Associate Professor of Ophthalmology and Senior Lecturer and Consultant Ophthalmologist, Department of Ophthalmology, School of Medical Sciences, Health Campus, Universiti Sains Malaysia, 16150 Kota Bharu, Kelantan, Malaysia.

E-mail: adilh@usm.my 


\section{Selulitis preseptal akibat gigitan serangga semut Charlie}

\section{Abstrak}

Selulitis preseptal adalah keadaan yang membimbangkan pada kanak-kanak. Salah satu penyebab yang paling biasa adalah dari gigitan serangga. Semut Charlie atau Paederus fuscipes telah dilaporkan sebagai agen penyebab dermatitis melalui kesan toksinnya, pederin. Tujuan laporan kes ini adalah untuk melaporkan kes selulitis preseptal akibat gigitan semut Charlie. Seorang gadis berusia dua tahun mengalami pembengkakan kelopak mata, kemerahan, dan kesakitan pada kedua-dua mata selama dua hari. Semut Charlie dilihat berada di atas batang hidung sebelum dia mengalami gejalapembengkakan kelopak mata pada kedua-dua belah, kemerahan dengan banyak pustula, kulit yang menggelupas, dan lelehan cecair dari mata. Dia dimasukkan ke wad dan dirawat dengan antibiotik. Rawatan yang diberikan menyebabkan pustula pecah danmeninggalkan kulit terdedah seterusnya keadaan bertambah baik. Selulitis preseptal boleh berlaku akibat penyebaran jangkitan berdekatan. Serangan oleh semut Charlie telah menjadi perhatian kesihatan awam. Tidak ada rawatan khusus untuk keadaan ini. Pengesanan awal dapat mengelakkan komplikasi.

Kata kunci: bengkak kelopak mata, gigitan serangga, Paederus fuscipes, selulitis preseptal, semut Charlie

\section{Introduction}

Preseptal cellulitis is an infection of the soft tissue of eyelids and periocular region anterior to the orbital septum. It is a worrying condition in infants and children younger than five years due to association with bacteraemia, septicaemia, and meningitis. 1 Several studies reported a mortality rate ranging from 5\% to 25\% of periorbital or orbital cellulitis with intracranial complication. ${ }^{2}$ Staphylococcus aureus is the most common bacterial pathogen in this situation. ${ }^{1}$ The pathogenesis can occur by three possible mechanisms: spread of infection from the upper respiratory tract, direct inoculation from trauma or insect bite, and spread of infection from the skin and adjacent structures. ${ }^{3}$

The Charlie ant, also known as rove beetle, is one of the most feared insects in Malaysia. It has been reported as a dermatitis-causing agent for the outbreak cases in Terengganu, Kelantan, and Penang. ${ }^{4}$ Since the 1990s, the Charlie ant has become a public health concern due to many outbreaks reported worldwide. ${ }^{4}$ This insect belongs to the family of Staphylinidae and its species is recognised 
as Paederus fuscipes. ${ }^{4}$ It features a dark orange body with black head and abdominal end (Fig. 1). When the insect is in contact with human skin, it releases a coelomic fluid that contains a toxin called pederin. ${ }^{4}$ It has been reported that the production of pederin depends on the activities of a pathogenic bacteria from the Pseudomonas sp. within the insect's body. ${ }^{4}$ The effects of this toxin on human skin cause peculiar dermatitis, also known as linear dermatitis, characterised by erythematous and bullous lesions. ${ }^{5}$

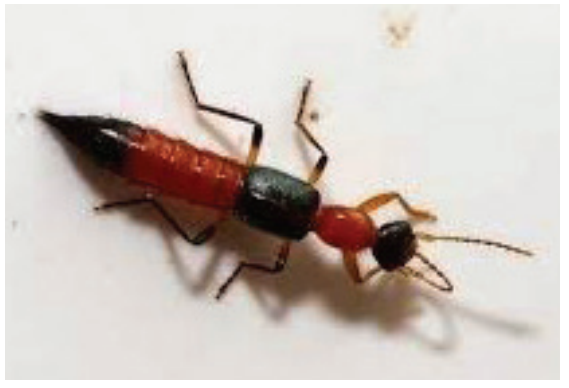

Fig. 1. Paederus fuscipes, commonly known as Charlie ant.

\section{Case report}

A two-year-old Malay girl with no known comorbidities presented to the emergency department of Hospital Universiti Sains Malaysia with bilateral eyelid swelling, redness, and pain for two days. Before this presentation, the patient's mother noted an insect called Charlie ant crawling on the patient's nasal bridge. There was no fever and no upper respiratory symptoms. However, her symptoms worsened, which led the patient to seek medical attention. She had no history of drug or food allergies.

On examination, visual acuity assessment was unreliable as the patient was uncooperative. However, she was able to fixate and follow near objects. On inspection, there was presence of generalised bilateral eyelid swelling, redness with multiple pustules, excoriated skin, and eye discharge (Fig. 2), which appeared worse on the left eyelid. There was no relative afferent pupillary defect, proptosis, or chemosis. Her bilateral extraocular movement was normal. The anterior and posterior segments revealed normal findings with normal intraocular pressure.
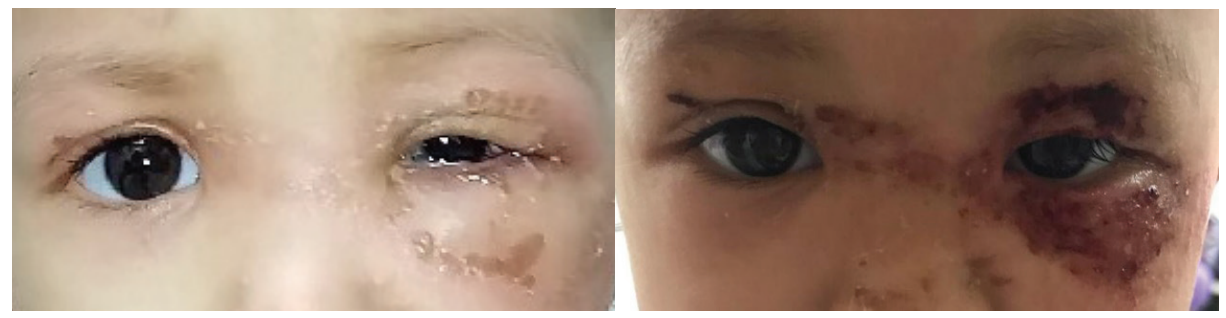

Fig. 2. (Left) Swelling, redness, and multiple pustules in both eyes. (Right) Swelling, redness, and multiple pustules in both eyes with more slough and excoriated skin with eye discharge noted on the second day of admission. 
Full blood count showed raised total white blood cell count. The left eyelid was swabbed for culture and sensitivity but obtained no growth. She was admitted and treated with intravenous augmentin and topical moxifloxacin for one week. During her admission, the pustules ruptured and she underwent daily normal saline dressing over her periorbital wound. Excoriated skin and slough were removed, leaving the periorbital skin exposed (Fig. 3). Chloramphenicol ointment was applied daily. The exposed area dried and healed quickly (Fig. 4). The patient was discharged and seen at the ophthalmology clinic two weeks later, at which point the condition had improved considerably (Fig. 5).

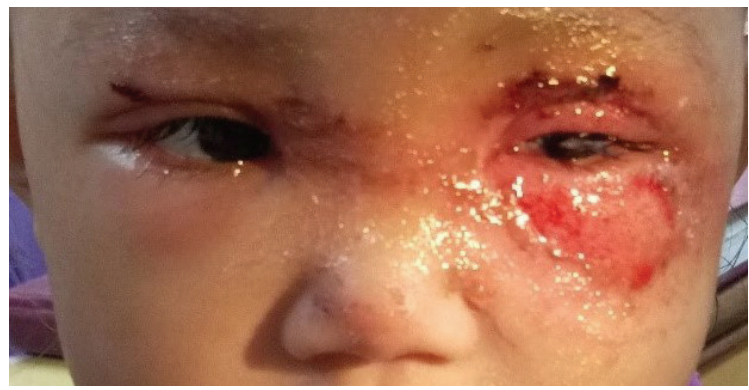

Fig. 3. After daily dressing with removal of slough and excoriated skin. Chloramphenicol ointment was applied.

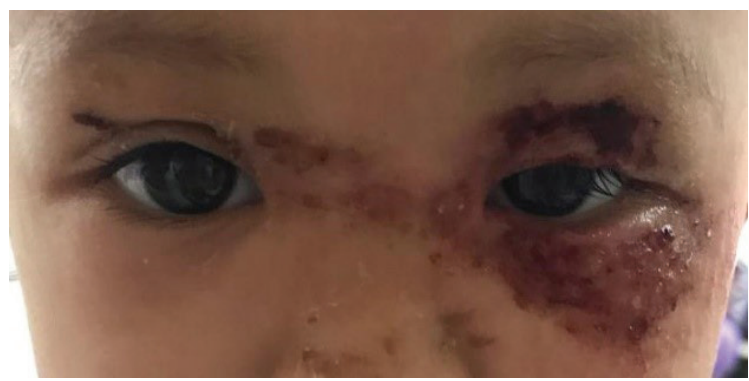

Fig. 4. The exposed skin dried and healing quickly.

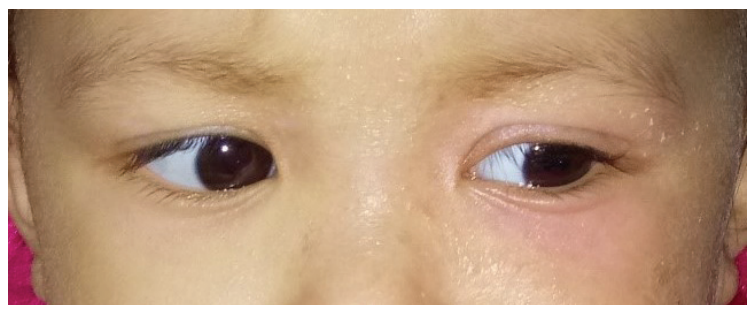

Fig. 5. Two weeks after being discharged from the ward, the wound was healing well with no apparent scar. 


\section{Discussion}

In this case report, the patient developed preseptal cellulitis secondary to a Charlie ant insect bite. Preseptal cellulitis is a contiguous spread of infection commonly caused by an insect bite. Ordinarily, skin reactions secondary to Charlie ant bite do not require admission. However, patients in this age group with signs of eyelid infection should be admitted for close observation.

History-taking and clinical examination played an important role in this patient. In the age group under six years of age, orbital cellulitis needs to be ruled out given that the orbital septum is not fully developed and consequently, the infection may spread posteriorly, causing severe complications. Investigations act as a guide for treatment. The raised total white blood cell count indicates an infection and the eye swab for culture and sensitivity was done to identify the responsible pathogen. Computed tomography is done only when complications are suspected or on difficult examination. ${ }^{3}$ This may help clinicians treat accordingly.

Usually, the effect of the Charlie ant causes the infected skin areas to be erythematous, itchy, and edematous after 24 to 48 hours from first contact. ${ }^{4}$ Several days later, the infected area may have visible scars which take a few weeks or months to disappear. ${ }^{4}$ Secondary infections often occur upon scratching, leading to extensive exfoliation and ulcerating dermatitis, which requires hospitalisation. ${ }^{4}$ The treatment is usually empirical. A patient who presents with preseptal cellulitis is treated with broad-spectrum topical and intravenous antibiotics. The complications that arise due to preseptal cellulitis may occur as the infection spreads posteriorly. The Charlie ant insect bite may also cause other ocular manifestations, such as conjunctivitis and keratoconjunctivitis. ${ }^{6}$

Several steps were taken by the district health office, such as fogging, termite medicine, and some environmental adjustments, to reduce the infestation of Charlie ants. However, this issue is something that needs to be further studied to determine definitive prevention methods to control outbreaks.

\section{Conclusion}

Preseptal cellulitis is a contiguous spread of infection commonly caused by an insect bite. Charlie ant bites have become a public health concern as they have been reported in many Malaysian states, especially in Kelantan. Unfortunately, there is no specific treatment for this condition. Early detection and close observation may prevent unexpected complications. 


\section{Declaration of patient consent}

The authors certify they have obtained consent from the patient's parents for the child's images and other clinical information to be reported in this journal.

\section{References}

1. American Academy of Ophthalmology. Orbit, Eyelids and Lacrimal System. San Francisco: Elsevier Academic Press; 2014. pp. 40.

2. Bae C, Bourget D. Periorbital cellulitis. In: StatPearls [Internet]. Treasure Island (FL): StatPearls Publishing; 2020 Jan. Accessed March 22, 2020. Available from: https://www.ncbi.nlm.nih.gov/bookb/ NBK470408.

3. Akçay EK, Can GD, Cagil N. Preseptal and orbital cellulitis. Journal of Microbiology and Infectious Diseases. 2014;4(03):123-127.

4. Wan FZ, Maryam S. Bugged by Bugs. School of Biological Sciences, Universiti Sains Malaysia. Bulletin Vol 2. 2014.

5. Iserson KV, Walton EK. Nairobi fly (Paederus) dermatitis in South Sudan: A case report. Wilderness Environ Med. 2012;23(3):251-254.

6. Zargari O, Kimyai-Asadi A, Fathalikhani F, Panahi M. Paederus dermatitis in northern Iran: a report of 156 cases. Int J Dermatol. 2003;42(8):608-612. 